\title{
Two new species of Hyalojassini (Hemiptera: Cicadellidae: Iassinae) to the genera Comanopa Blocker and Gehundra Blocker, description of the male of $G$. sordida (Baker) and key to species
}

\author{
Alexandre C. DOMAHOVSKI \\ Departamento de Zoologia, Universidade Federal do Paraná. Caixa Postal 19020, \\ 81531-980 Curitiba, PR, Brazil. \\ Email: domahovskiac@yahoo.com.br \\ (- https://orcid.org/0000-0003-4588-4236
}

urn:Isid:zoobank.org:author:0B988BD5-599B-42CE-ADCB-50FC813E104E

\begin{abstract}
Comanopa Blocker, 1979 and Gehundra Blocker, 1976 are small and poorly known genera of leafhoppers, previously comprising four and five species, respectively. In this study, two new species are proposed: Comanopa mananciensis sp. nov. from the state of Paraná, Southern Brazil, and Gehundra cristalinensis sp. nov. from the state of Mato Grosso, Centralwestern Brazil. The male of Gehundra sordida (Baker, 1900) is studied by the first time. Detailed descriptions and illustrations of males and females are provided and keys to males of Comanopa and Gehundra are given.
\end{abstract}

Keywords. Auchenorrhyncha, leafhoppers, morphology, Neotropical region, taxonomy.

Domahovski A.C. 2021. Two new species of Hyalojassini (Hemiptera: Cicadellidae: Iassinae) to the genera Comanopa Blocker and Gehundra Blocker, description of the male of G. sordida (Baker) and key to species. European Journal of Taxonomy 746: 112-129. https://doi.org/10.5852/ejt.2021.746.1323

\section{Introduction}

Cicadellidae Latreille, 1825 is the largest family of Hemiptera Linnaeus, 1758 and one of the most successful radiations of plant-feeding insects known as leafhoppers, currently classified into 25 subfamilies (Krishnankutty et al. 2016). The Neotropical region has the richest fauna of leafhoppers, with more than 5000 described species (Freytag \& Sharkey 2002).

The subfamily Iassinae Walker, 1870 is distributed worldwide and is one of the most diverse subfamilies of Cicadellidae, including more than 2000 species currently placed in 184 genera and 12 tribes (Dai et al. 2015; Krishnankutty et al. 2016; Domahovski 2020; Dietrich et al. 2020). In the New World, Iassinae comprises approximately 113 genera and 1566 species belonging to six tribes: Bythoniini Linnavuori, 1959; Gyponini Stål, 1870; Hoplojassini Krishnankutty et al., 2016; Lipokrisnini Krishnankutty et al., 2016; Selenomorphini Evans, 1974; and Hyalojassini Evans, 1972 (Dai \& Dietrich 2015; Krishnankutty et al. 2016; Gaiani 2017; Freytag 2018; Domahovski 2019, 2020; Domahovski \& Cavichioli 2019a, 2020; Domahovski et al. 2020; Gonçalves et al. 2020). 
Hyalojassini comprises small and ovate leafhoppers, between 3.5 to $8.0 \mathrm{~mm}$ in length, which can be recognized mainly by the head usually rounded in profile, without distinctly delimited crown; the forewing with inner apical cell usually more membranous than adjacent cells; the hind wing with veins R4+5 and M1+2 confluent distally; male subgenital plates usually very short or vestigial and completely concealed by pregenital sternite; and the female genitalia with first valvula with dorsal sculpturing usually areolate and second valvula with few widely spaced dorsal teeth (Krishnankutty et al. 2016). Hyalojassini is distributed in SE Asia (9 genera and 32 species) and the New World (29 genera and 117 species), representing an interesting biogeographical disjunction (Dai et al. 2015; Krishnankutty et al. 2016; Wang et al. 2018; Domahovski \& Cavichioli 2019c; Domahovski 2020). Although most of the of hyalojassine species are described from the Neotropical region (more than $70 \%$ of the known species), the real diversity of the tribe remains poorly known, especially in Brazil, where only 12 genera and 21 species were previously recorded (Defea \& Paradell 2019; Domahovski \& Cavichioli 2019b, 2019c; Domahovski 2020).

Blocker (1976) described the genus Gehundra with three new species from Peru, Gehundra tricosa (type species), G. avulsa and G. galbina, each known from a single male specimen, and provided a key to the species. Blocker (1979) transferred Bythoscopus pallidus Osborn, 1924 and Macropsis sordidus Baker, 1900 to Gehundra, both species known from a single female specimen from Brazil.

Comanopa was described by Blocker (1979) with Stragania puertoricensis Caldwell, 1952 from Puerto Rico (type species), Stragania fasciata Linnavuori, 1956 from Brazil (only know by female specimens) and one species describe as new, Comanopa adelpha from Panamá and Mexico. Blocker (1982) described the last species, Comanopa hamiltoni from Jamaica.

This study aims to contribute to the knowledge of Hyalojassini by describing two new species belonging to the genera Comanopa and Gehundra. Additionally, one male and four females of Gehundra sordida (Baker, 1900), from the state of Mato Grosso do Sul, Centralwestern Brazil, are studied and the male and female genitalia are described for the first time.

\section{Material and methods}

The descriptive terminology adopted herein follows mainly Young $(1968,1977)$, except for head features (Hamilton 1981; Mejdalani 1998), wings (Dietrich 2005) and leg chaetotaxy (Rakitov 1997). The term gonoplac follows Mejdalani (1998) and pseudostyle (thickened portion along the inner margin of the subgenital plate) follows Kramer (1963) and Blocker (1979). The techniques used for dissection of male and female terminalia follow Oman (1949), with the few modifications described by Cavichioli \& Takiya (2012).The dissected parts are stored in microvials with glycerin which are pinned bellow the specimen.

Illustrations were prepared according to the procedures described by Domahovski \& Cavichioli (2019b). Label data are specified between quotation marks, with a backslash (\) separating the lines on the labels. Square brackets ([ ] ) are used to additional abbreviated information.

The specimens are deposited in the Coleção Entomológica Pe. Jesus Santiago Moure, Universidade Federal do Paraná, Curitiba, Brazil (DZUP) and Coleção Entomológica Prof. José Alfredo Pinheiro Dutra, Departamento de Zoologia, Instituto de Biologia, Universidade Federal do Rio de Janeiro, Rio de Janeiro, Brazil (DZRJ).

\section{Abbreviations}

$\mathrm{AD}=$ anterodorsal

$\mathrm{AV}=$ anteroventral 


$$
\begin{aligned}
& \mathrm{PD}=\text { posterodorsal } \\
& \mathrm{PV}=\text { posteroventral } \\
& \mathrm{IC}=\text { intercalary }
\end{aligned}
$$

\title{
Results
}

\author{
Class Insecta Linnaeus, 1758 \\ Order Hemiptera Linnaeus, 1758 \\ Suborder Auchenorrhyncha Duméril, 1806 \\ Infraorder Cicadomorpha Evans, 1946 \\ Superfamily Membracoidea Rafinesque, 1815 \\ Family Cicadellidae Latreille, 1825 \\ Subfamily Iassinae Walker, 1870 \\ Tribe Hyalojassini Evans, 1972 \\ Genus Comanopa Blocker, 1979
}

\section{Type species}

Stragania puertoricensis Caldwell, 1952.

\section{Diagnosis}

Forewing (Fig. 1) with vein separating appendix and first apical cell incomplete (evanescent apically). Male pygofer (Fig. 6) with process (pygofer hooks) arising near apex, extending anterad, similar to Penestragania Beamer \& Lawson, 1945. Subgenital plate (Fig. 8) simple, slightly reduced in size, similar to Momoria Blocker, 1979. Style (Fig. 9) reduced in length. Connective (Fig. 9) like a narrow semicircular band.

Comanopa mananciensis sp. nov. urn:1sid:zoobank.org:act:1496BF6F-94E4-4E89-92EB-1E7457C88C06

Figs $1-12$

\section{Diagnosis}

Head and thorax (Figs 1-3) brownish-yellow. Face (Fig. 3) with crown-face transition black. Male pygofer (Figs 5-7) with pair of processes arising near base of plates, short and rounded apically; ventral margin of pygofer strongly produced ventrad. Aedeagus (Figs 11-12) with shaft deeply split apically, whit pair of subapical processes directed laterally.

\section{Etymology}

The new species name refers to the locality (Mananciais da Serra) where the holotype was collected.

\section{Material examined}

\section{Holotype}

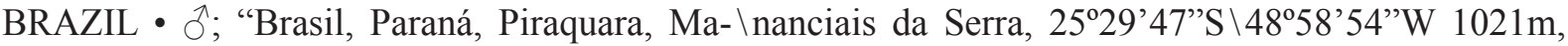
Sweep, \21-28.XI.2018, A.P. Pinto, B.R. \Araujo \& A.C. Domahovski”; DZUP 215440.

\section{Paratype}

BRAZIL - 1 đ̃; "Brasil, PR [Paraná], S. [São] J. [José] dos Pinhais \Rep. [Represa] Guaricana, Luz $\backslash 25.7150^{\circ} \mathrm{S} 48.9711^{\circ} \mathrm{W} \backslash 750$ a 400m 12-14.XII.2017 $\backslash$ Cavichioli \& Domahovski”; DZUP 215441. 


\section{Description}

\section{Male}

Measurements (mm). Holotype (ð) total length 3.8. Paratype (ふ) 4.0.

BoDy. Small and ovate leafhoppers, not depressed dorsoventrally.

HEAD (Figs 1-3). Dorsal view: very short, transocular width nine-tenths humeral width of pronotum; crown not developed, nearly vertical, median length $1 / 10$ of interocular width, surface with transverse striae; anterior and posterior margins parallel and broadly rounded; ocelli not visible dorsally; lateral view: crown-face transition broadly rounded with transverse striae; frons slightly inflated; clypeus almost flat; ventral view: face less than two times wider than high; ocelli small, on anterior margin, mesad of antennal pits and distant from eyes; frons with transverse striae, lateral margins strongly convergent ventrally; frontogenal suture extending to antennal ledges; antennal ledge carinate and slightly oblique, not concealing antennal base; antenna length ca $1 / 3$ width of head; gena broad, with small setae; ventrolateral margin broadly rounded, completely concealing proepisternum; maxillary plate produced ventrally as far as clypeus apex; lorum broad, with short setae, maximum width approximately equal to that of clypeus, subgenal suture rounded, extended nearly to midlength of lateral margin of frons; clypeus slightly longer than wide, epistomal suture complete and straight, lateral margins parallel, apex carinated and straight.

Pronotum (Figs 1-2). Dorsal view: anterior margin broadly rounded, posterior margin slightly excavated; surface without setae, with transverse striae, except on anterior third; lateral margins convergent anterad, carinate, slightly shorter than eye length; lateral view: convex and declivous anterad.

Mesonotum and scutellum (Fig. 1). Dorsal view: as long as pronotum length; surface with transverse striae; scutellum flat.

FoREWING (Figs 1-2). Many small erect setae, venation obscure; clavus truncate apically; appendix and first apical cell more membranous than adjacent cells, glabrous, vein separating appendix and first apical cell evanescent apically; 3 closed anteapical cells and 4 apical cells $\left(2^{\text {nd }}, 3^{\text {rd }}\right.$ and $4^{\text {th }}$ cells short; R1 vein absent).

HIND wING. Veins R4+5 and M1+2 fused apically.

LEGS. Profemur moderately elongated, 2.7 times longer than high; PD, AD and AM rows formed by undifferentiated setae, PD1 and AD1 setae short and AM1 absent; IC row formed by double row of fine setae, continuous with AV row; AV and PV rows formed by several fine setae. Protibia, in crosssection, almost circular; AV row formed by short, thin setae in the basal half and slightly more robust setae distally; AD row consisting of only undifferentiated setae; PD row with 3 long setae intercaled by undifferentiated setae; PV row with 3-4 long setae intercaled by undifferentiated setae. Hind leg with femoral setal formula 2:2:1; PD2 seta reduced in size; metatibia PD, AD and AV rows with 15-16, 9-10 and 9-10 macrosetae respectively; AD row without intercalary setae between macrosetae; PV row with setae of apical half intercalating 1 longer and thicker seta and 3-4 shorter and thinner setae, ending with 2 very short, thin setae; first tarsomere without enlarged dorsoapical seta; ventral surface with two longitudinal rows of simple (non-cucullate) thin setae; pecten with 4 platellae flanked by tapered lateral setae; second tarsomere pecten with 2 platellae flanked by tapered lateral setae.

Coloration. Head and thorax (Figs 1-3) brownish-yellow. Face (Fig. 3) with crown-face transition black. Mesonotum (Fig. 1) dark brown; scutellum brownish-yellow with lateral margins light-yellow. Forewing (Figs 1-2) with black setae. Legs (Figs 2-3) hind tibia with cucullate bases of macrosetae black.

Terminalia. Sternite VIII (Fig. 4) convex, moderately produced posterad, 1.2 times wider than long, shorter than sternites VII and VI combined; ventral surface with many small setae; lateral angles 


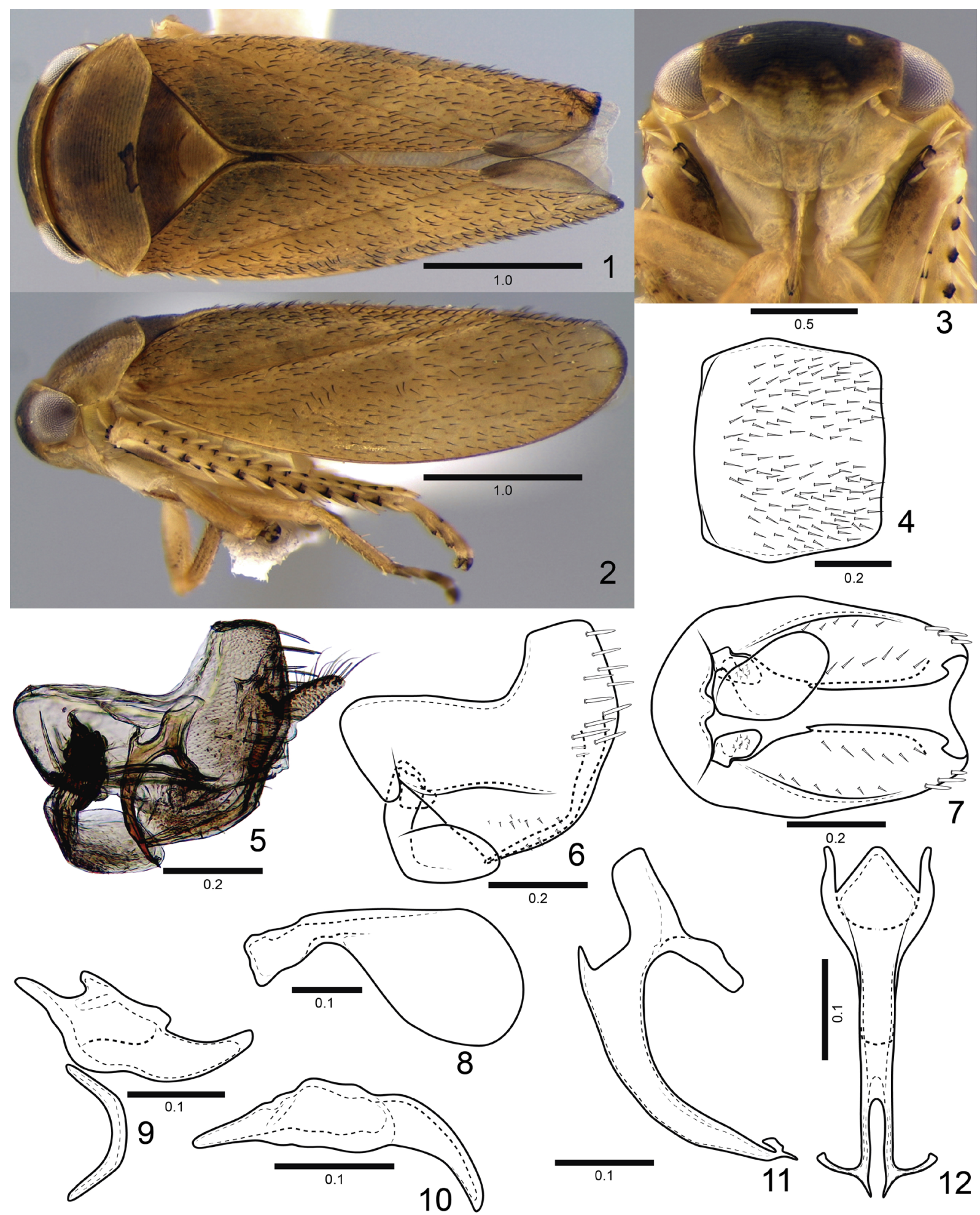

Figs 1-12. Comanopa mananciensis sp. nov., holotype, $\widehat{\jmath}$ (DZUP 215440). 1. Habitus, dorsal view. 2. Habitus, lateral view. 3. Head, ventral view. 4. Sternite VIII, ventral view. 5. Genital capsule, lateral view. 6. Pygofer, valve and subgenital plate, lateral view. 7. Pygofer, valve and subgenital plate (left subgenital plate removed), ventral view. 8. Subgenital plate, ventral view. 9. Connective and style, dorsal view. 10. Style, lateral view. 11. Aedeagus, lateral view. 12. Aedeagus, anterior view. Scale bars in $\mathrm{mm}$. 
rounded; posterior margin straight. Valve (Figs 5-7) broadly fused laterally to pygofer; ventral margin excavated laterad of small median lobe. Pygofer (Figs 5-7) with pair of processes arising near base of plates, short and rounded apically, ventral surface with short setae. In lateral view, pygofer (Fig. 6) higher on apical half; dorsal margin widely notched on basal $2 / 3$; dorsoposterior margin fused to pygofer lobes; ventral margin strongly produced ventrad, with short setae forming two longitudinal lines, internal process fused to pygofer lobe, arising near apex and bordering ventral margin, forming a small dentiform protrusion near apex of subgenital plate; lateral surface with longitudinal carina on basal 2/3; apex very wide and truncated; few macrosetae dispersed near apex. Anal tube (Fig. 5) membranous, without processes. Subgenital plate (Figs 5-8) short, not overlapping pygofer laterally, produced posteriorly as far as half length of pygofer; ventral surface without setae; anterior portion elongated and curved dorsally; apical portion expanded and ovate; apex rounded. Connective (Fig. 9), thin, slightly arched bar. Style (Figs 9-10), short, not surpassing apex of subgenital plates; apex curved ventrad in lateral view; apex subacute, slightly curved outward in dorsal view. In lateral view, aedeagus (Fig. 11) with preatrium moderately developed, produced anterad; dorsal apodeme developed, anterior margin forming pair of flattened divergent arms truncated apically, directed dorsally, posterior margin produced ventrally; shaft directed ventrally, slightly curved posterad and tapered apically. In anterior view, aedeagus (Fig. 12) with shaft deeply split apically, whit pair of subapical processes long, directed laterally; gonopore subapical.

\section{Female}

Unknown.

\section{Remarks}

The known species of Comanopa have subgenital plates and styles very similar to each other, but can be separated by the shape of pygofer and aedeagus. Comanopa mananciensis sp. nov. can be easily recognized by the pygofer (Fig. 6) with ventral margin strongly produced ventrad and the aedeagus (Fig. 12) deeply split apically, with pair of long subapical processes, directed laterally.

Key to males of Comanopa (C. fasciata only known from the female)

1. In posterior view, aedeagus without subapical processes

- In posterior view, aedeagus with subapical processes (Fig. 12)

2. Pygofer with processes poorly developed, not exceeding the ventral margin (Blocker 1982: 646, fig. 28). In posterior view, aedeagus not split apically

C. hamiltoni Blocker, 1982 (Jamaica)

- Pygofer with processes developed, exceeding the ventral margin (Blocker 1979: 37, fig. 77). In posterior view, aedeagus split apically

C. puertoricensis (Caldwell, 1952) (Puerto Rico)

3. In posterior view, aedeagus with subapical processes very short, triangular-shaped (Blocker 1979: 37, fig. 79)

C. adelpha Blocker, 1979 (Panama)

- In posterior view, aedeagus with subapical processes long, directed laterally (Fig. 12)

C. mananciensis sp. nov. (Brazil)

Genus Gehundra Blocker, 1976

\section{Type species}

Gehundra tricosa Blocker, 1976.

\section{Diagnosis}

Body (Figs 13, 32) moderately large and robust. Forewing (Figs 13, 32) with groups of black setae on apical half and vein separating appendix and first apical cell complete. Male sternite VIII 
(Figs 16,35) very long, reaching the apex of pygofer, in repose. Pygofer with (Figs 17-18) or without (Figs 37-38) long setae on ventral margin Subgenital plate (Figs 18, 20, 37, 39) with external margin lobed, overlapping the lateral portion of pygofer and with well developed pseudostyles. Connective amorphous

\author{
Gehundra cristalinensis sp. nov. \\ urn:1sid:zoobank.org:act:25FBE065-ECF1-4D42-9AF4-A82F25D83058
}

Figs 13-31

\title{
Diagnosis
}

Male pygofer (Figs 17-19) ventral margin with long thin setae on apical half. Subgenital plate (Figs 1720) with external margin rounded, almost circular; apex deeply notched, pseudostyle acute, with few short setae. Style (Fig. 21) approximately straight; apex slightly tapered and curved dorsally.

\section{Etymology}

The new species name refers to the locality (Parque Estadual do Cristalino) where the type series was collected.

\section{Material examined}

\section{Holotype}

BRAZIL - Ј;; "Brasil, MT [Mato Grosso], Novo Mundo, Pq. [Parque] $\backslash$ Est. [Estadual] do Cristalino, 09.4517 ${ }^{\circ} \mathrm{S}, \backslash 55.8396^{\circ} \mathrm{W}, 240 \mathrm{~m}$, light trap, $\backslash 21-25 . v i .2017$, RR Cavichioli $\backslash \&$ AC Domahovski”; DZUP 215443.

\section{Paratypes}

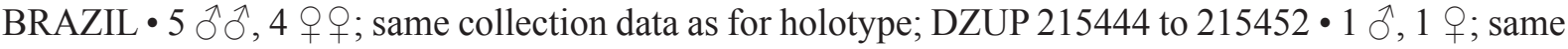
collection data as for holotype; DZRJ • 1 क ; "Brasil, MT, Novo Mundo, $\backslash$ Pq. Est. do Cristalino, $\backslash 09.4517^{\circ} \mathrm{S}$ $55.8396^{\circ} \mathrm{W}, \backslash 240 \mathrm{~m}$, luminárias - aloja $\backslash$ mento AC Domahovski”; DZUP 215453.

\section{Description}

\section{Male}

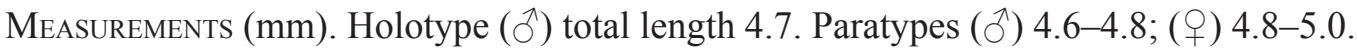

BoDy. Small and ovate leafhoppers, not depressed dorsoventrally.

HEAD (Figs 13-15). Dorsal view: very short, transocular width nine-tenths humeral width of pronotum; crown not developed, vertical, surface whit transverse striae; anterior and posterior margins parallel and broadly rounded; ocelli not visible dorsally; lateral view: crown-face transition broadly rounded with transverse striae; frons and clypeus slightly inflated; ventral view: face more than two times wider than high; ocelli small, on anterior margin, mesad of antennal pits and distant from eyes; frons with transverse striae, lateral margins strongly convergent ventrally; frontogenal suture surpassing antennal ledge, extending to anterior margin of crown; antennal ledge carinate and slightly oblique, not concealing antennal base; antenna length ca $1 / 3$ width of head; gena broad, with small setae; ventrolateral margin broadly rounded, completely concealing proepisternum; maxillary plate produced ventrally as far as clypeus apex; lorum with few short setae, narrower than clypeus width, subgenal suture rounded, extended nearly to midlength of lateral margin of frons; clypeus slightly shorter than basal width, epistomal suture complete and rounded, lateral margins excavated medially, apex slightly broadened, rounded and carinated. 
Pronotum (Figs 13-14). Dorsal view: anterior margin broadly rounded, posterior margin slightly excavated; surface without setae, with transverse striae, except on anterior third; lateral margins convergent anterad, carinate, slightly shorter than eye length; lateral view: convex and declivous anterad.

Mesonotum And scutellum (Fig. 13). Dorsal view: longer than pronotum length; surface with transverse striae, except lateral angles with texture shagreen; scutellum flat.

FoREWING (Figs 13-14). With many small erect setae, venation obscure; clavus truncate apically; vein separating appendix and first apical cell complete (not evanescent apically), appendix and first apical cell broad, more membranous than adjacent cells, glabrous; 3 closed anteapical cells and 4 apical cells $\left(2^{\text {nd }}, 3^{\text {rd }}\right.$ and $4^{\text {th }}$ cells short; $\mathrm{R} 1$ vein absent $)$.

HIND wING. Veins R4+5 and M1+2 fused apically.

Legs. Profemur moderately elongated, 2.9 times longer than high; PD, AD and AM rows formed by undifferentiated setae, PD1 and AD1 setae short and AM1 absent; IC row formed by double row of fine setae, continuous with AV row; AV and PV rows formed by several fine setae. Protibia, in cross-section, almost circular, without defined longitudinal carina adjacent to PD row; AV row formed by short, thin setae in the basal half and slightly more robust setae distally; AD row consisting of only undifferentiated setae; PD row formed by with 3-4 long setae intercaled by undifferentiated setae; PV row with 6-7 short setae. Hind leg with femoral setal formula 2:2:1 or 2:2:1:1; PD2 seta reduced in size; metatibia PD, AD and AV rows with 14-19, 9-11 and 10-12 macrosetae respectively; AD row without intercalary setae between macrosetae; PV row with setae of apical half intercalating 1 longer and thicker seta and 3-4 shorter and thinner setae, ending with 3 thin setae; first tarsomere without enlarged dorsoapical seta; ventral surface with two longitudinal rows of simple (non-cucullate) thin setae; pecten with 4 platellae flanked by tapered lateral setae; second tarsomere pecten with 2 platellae flanked by tapered lateral setae.

Coloration. Head and thorax (Figs 13-15) brownish-yellow. Face (Fig. 15) with muscle impressions of frons brown; lorum with ventral half brown. Pronotum (Fig. 13) with irregular brown markings near anterior margin. Mesonotum (Fig. 13) with lateral angles dark brown. Forewing (Figs 13-14) with brown setae and groups of black setae at midlength of anal margin, apex of clavus and apex of inner discal cell (variable in intensity between the specimens).

Terminalia. Sternite VIII (Fig. 16) convex, strongly produced posterad, two times longer than wide, longer than sternites VII and VI combined; ventral surface with many small setae, except basal portion and along median line; lateral margins tapered toward apex, with small rounded lobe at basal third; apex subacute. Valve (Figs 17-18) longer than wide, broadly fused laterally to pygofer; lateral margins convergent toward ventral margin, with strong integument thickening; ventral margin rounded. In lateral view, pygofer (Figs 17-18) without processes, higher near base; dorsal margin deeply notched after half its length; dorsoposterior margin fused to pygofer lobes, straight and oblique; ventral margin approximately straight, with short setae near base and long thin setae on apical half; lateral surface with longitudinal carina near ventral margin of basal 2/3; apex very wide and truncated; without macrosetae, but with few short setae near apex. In ventral view, pygofer (Fig. 19) with ventral margin folded inward, from base to apex, with short setae on inner surface. Anal tube (Fig. 17) membranous, without processes. Subgenital plate (Figs 17-20) short, with well developed pseudostyle; inner margin nearly straight; external margin rounded, almost circular, overlapping pygofer laterally; apex deeply notched, pseudostyle acute, with few short setae. Connective amorphous. Style (Figs 17, 21) long, approximately straight, apodeme and apophysis long, subequal in length; apex slightly tapered and curved dorsally. Aedeagus (Figs 22-23), with preatrium not developed; dorsal apodeme developed, with lateral margins extended laterad and posterior margin extending to almost apex of shaft; shaft slightly curved dorsally; 

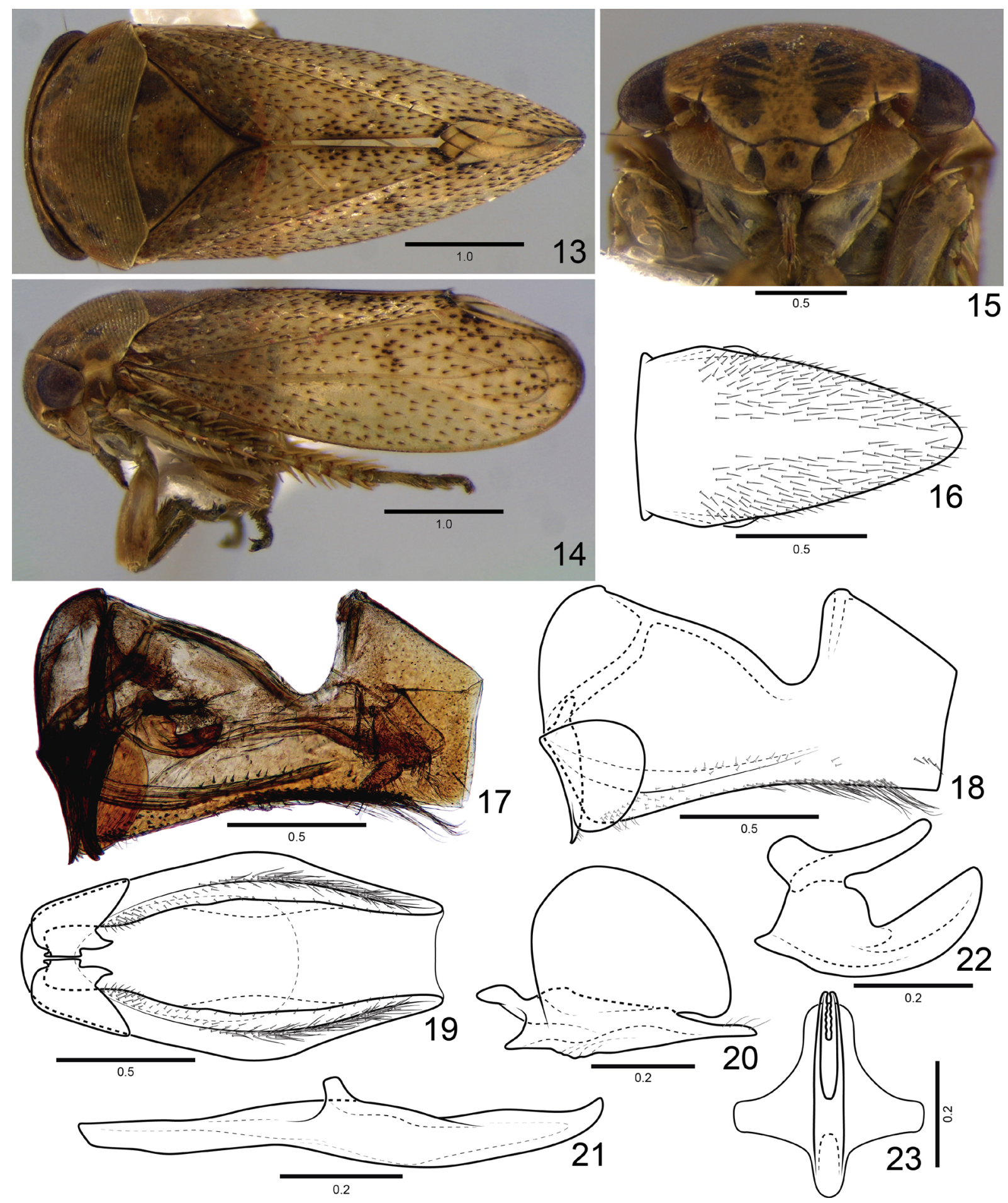

Figs 13-23. Gehundra cristalinensis sp. nov., holotype, $\widehat{\jmath}$ (DZUP 215443). 13. Habitus, dorsal view. 14. Habitus, lateral view. 15. Head, ventral view. 16. Sternite VIII, ventral view. 17. Genital capsule, lateral view. 18. Pygofer, valve and subgenital plate, lateral view. 19. Pygofer, valve and subgenital plate, ventral view. 20. Subgenital plate, ventral view. 21. Style, lateral view. 22. Aedeagus, lateral view. 23. Aedeagus, ventral view. Scale bars in $\mathrm{mm}$. 
dorsal margin rounded near base and straight distally; ventral margin broadly rounded. In ventral view, aedeagus (Fig. 23) with shaft apex bifid; gonopore subapical.

\section{Female}

Terminalia. Sternite VII (Figs 24-25) ca two times wider than long; ventral surface with short setae; posterior margin deeply excavated, V-shaped. Internal sternite VIII membranous. Pygofer (Figs 24, 26)

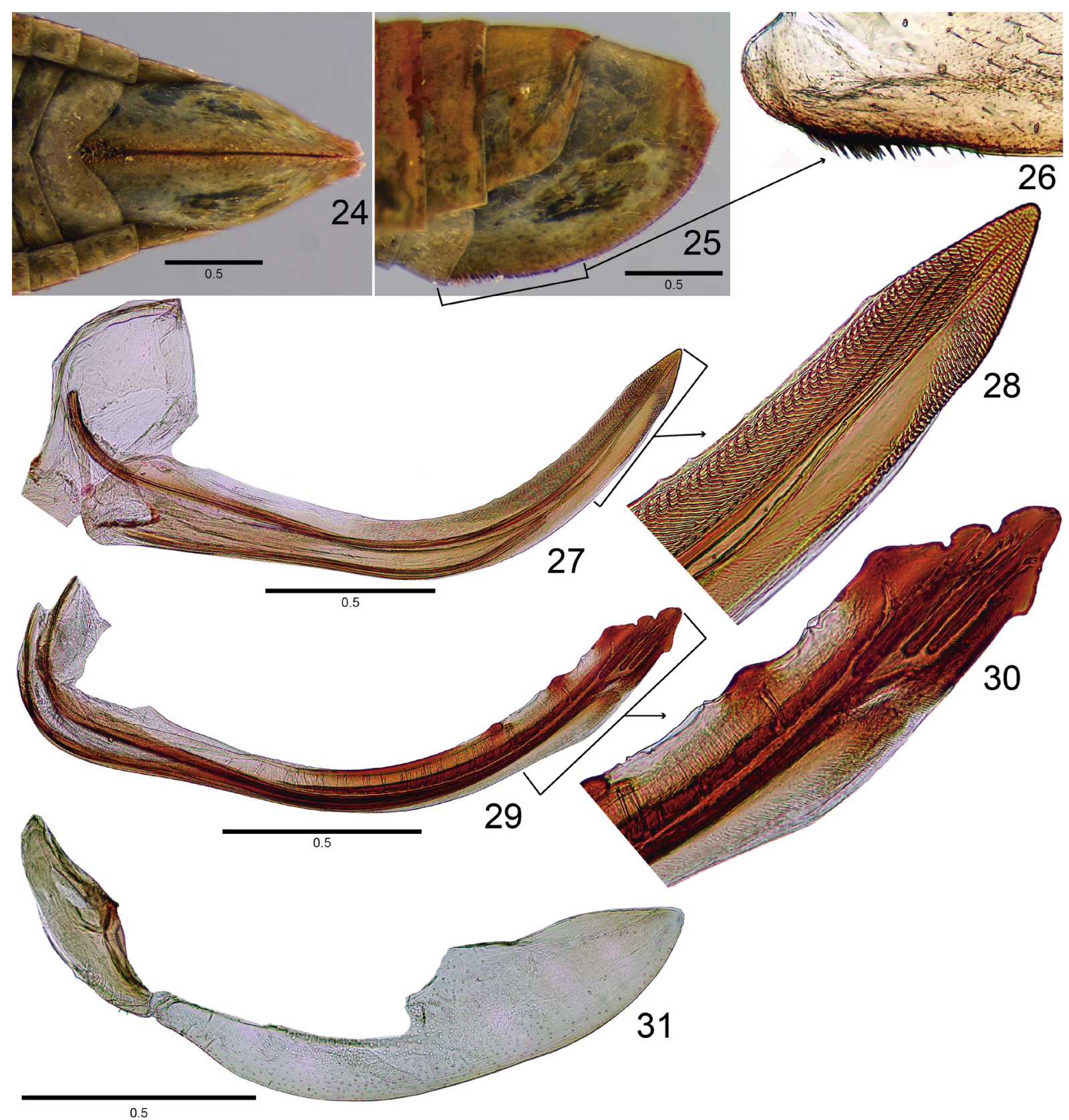

Figs 24-31. Gehundra cristalinensis sp. nov., paratype, $q$ (DZUP 215451). 24. Apical portion of abdomen, ventral view. 25. Apical portion of abdomen, lateral view. 26. Enlarged view of basal portion of pygofer. 27. First valvifer and first valvula, lateral view. 28. Apical portion of first valvula. 29. Second valvula, lateral view. 30. Apical portion of second valvula. 31. Second valvifer and gonoplac, lateral view. Scale bars in $\mathrm{mm}$. 
with many thin setae; ventral margin broadly rounded with group of thick setae at base; apex obliquely truncated. Ovipositor slender, evenly curved dorsad, not surpassing pygofer apex. First valvifer (Fig. 27) trapezoid, approximately as long as wide; anterior margins of both valvifers connected by sclerotized membrane. First valvula (Fig. 27) with dorsal and ventral margins almost parallel, slightly convergent apically, ca 7 times longer than high at base; ventral interlocking device long, extending over basal $2 / 3$; dorsal sculptured area areolate starting before the midlength; apical portion (Fig. 28) with ventral sculpture present only near apex, continuous with the dorsal sculpture, apex moderately tapered and acute. Second valvifer (Fig. 31) ca three times higher than long. Second valvula (Fig. 29) ca 10 times longer than high; dorsal and ventral margins parallel; dorsal margin with three distinct subapical teeth widely spaced; apical portion (Fig. 30) of dorsal margin with two rounded subapical notches forming one rounded tooth between apex and first subapical tooth; ventral margin without denticles and with one subapical tooth. Gonoplac (Fig. 31) four times longer than high; dorsoapical margin long, half length of gonoplac; external surface without dentiform cuticular projections; ventral margin broadly rounded, with few spaced macrosetae near ventral margin; apex rounded.

\section{Remarks}

Gehundra cristalinensis sp. nov. is most similar to G. avulsa in having the male pygofer with ventral margin bearing long setae on apical half and the subgenital plate deeply notched apically. However, the new species can easily by separated by the subgenital plate (Fig. 20) with external margin rounded, almost circular (less expanded laterally and not circular in G. avulsa) and the style (Fig. 21) approximately straight, with apex slightly tapered (style with apophysis more curved, with apex footshaped in G. avulsa).

\section{Gehundra sordida (Baker, 1900)}

Figs 32-49

Macropsis sordidus Baker, 1900: 56.

Bythoscopus sordidus - Oman 1936: 354.

Stragania sordida - Linnavuori 1956: 18.

Iassus sordidus - Metcalf 1966: 90.

Gehundra sordida - Blocker 1979: 23, fig. 24.

\section{Diagnosis}

Pygofer (Figs 36-38) ventral margin excavated basally, with rounded lobe at basal third, and short, thick setae grouped in line near midlength. Subgenital plate (Figs 36-39) with external margin with rounded lobe on basal half; apex of pseudostyle subacute, with thin setae along external margin and group of thicker setae on apex. Style (Fig. 40) with apophysis straight, apex rounded, curved dorsally.

\section{Material examined}

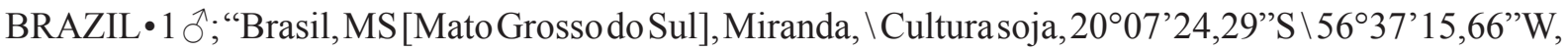
$122 \mathrm{~m}, \backslash$ 02.II.2016, A. Specht, W. R. F. \de Camargo \& H.V.B. Concone"; DZUP 215454 • 2 우; same collection data as for preceding; "03.II.2016"; DZUP 215455-215456 • 1 q; same collection data as for

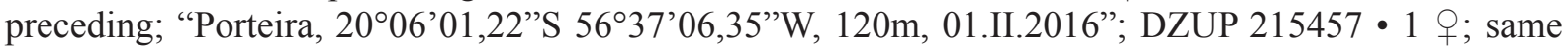
collection data as for preceding; "Nativa-campo, $20^{\circ} 06^{\prime} 20,20^{\prime}$ "S 56 36 '52,62"W, 121m, 14.XI.2015"; DZUP 215458.

Description (external characters as in the preceding description)

\section{Male}

MEAsuREMEnTs (mm). Total length (ð), 4.5; () 4.5-4.8. 

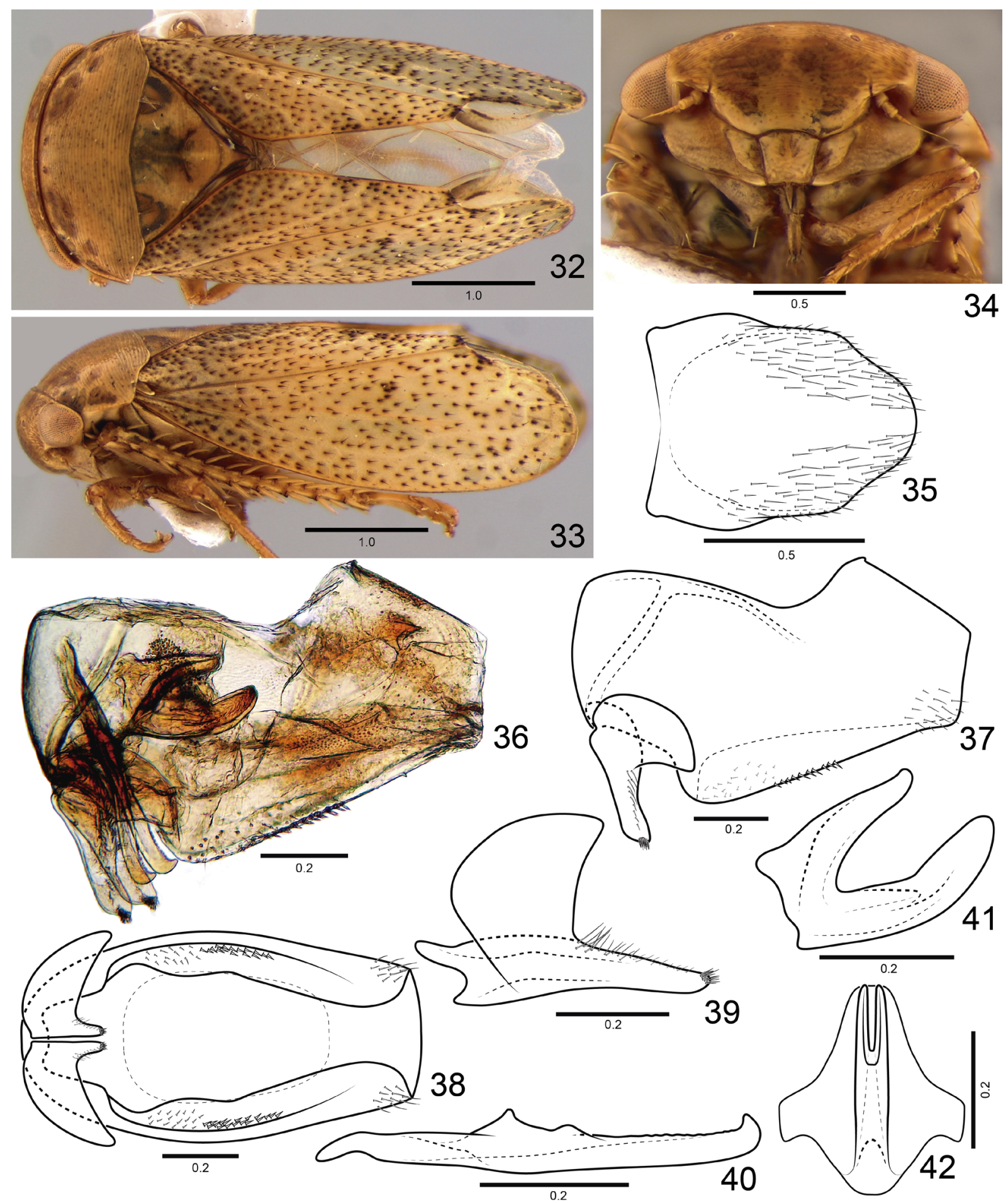

Figs 32-42. Gehundra sordida (Baker, 1900), ô (DZUP 215454). 32. Habitus, dorsal view. 33. Habitus, lateral view. 34. Head, ventral view. 35. Sternite VIII, ventral view. 36. Genital capsule, lateral view. 37. Pygofer, valve and subgenital plate, lateral view. 38. Pygofer, valve and subgenital plate, ventral view. 39. Subgenital plate, ventral view. 40. Style, lateral view. 41. Aedeagus, lateral view. 42. Aedeagus, ventral view. Scale bars in $\mathrm{mm}$. 
Coloration. Head and thorax (Figs 32-34) brownish-yellow. Pronotum (Fig. 32) with irregular brown markings near anterior margin. Mesonotum (Fig. 32) with lateral angles dark brown. Forewing (Figs 3233 ) with brown setae and groups of black setae at midlength of anal margin, apex of clavus and apex of inner discal cell (variable in intensity between the specimens).

Terminalia. Sternite VIII (Fig. 35) convex, strongly produced posterad, 1.5 times longer than wide, longer than sternites VII and VI combined; ventral surface with many small setae, except basal portion and along median line; lateral margins with small rounded lobe at basal third; apex abruptly tapered and rounded. Valve (Figs 36-37) longer than wide, broadly fused laterally to pygofer; lateral margins convergent toward ventral margin, with strong integument thickening; ventral margin rounded. In lateral view, pygofer (Figs 36-37) without processes, higher near basal third; dorsal margin notched after half

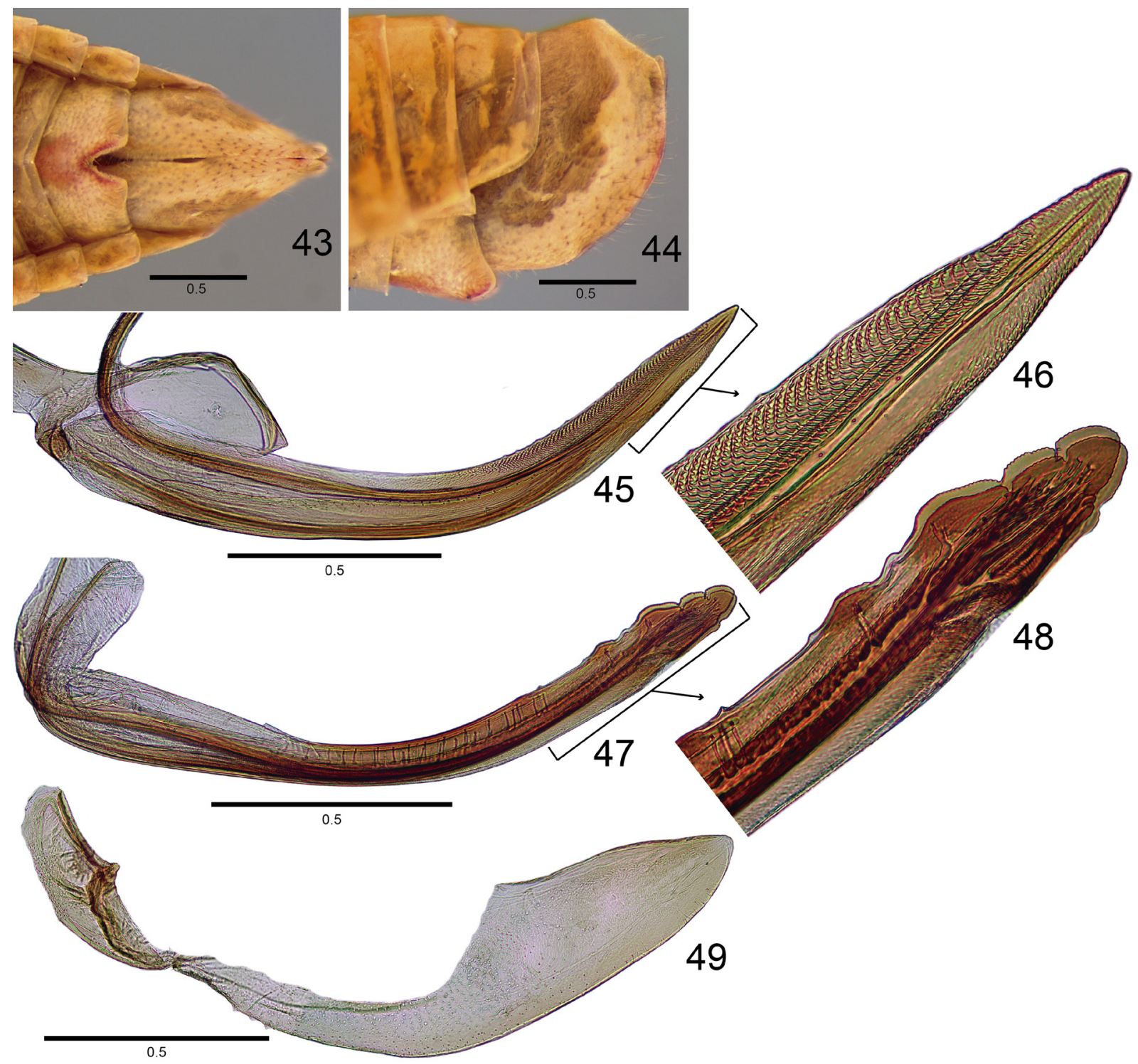

Figs 43-49. Gehundra sordida (Baker, 1900), ㅇ (DZUP 215455). 43. Apical portion of abdomen, ventral view. 44. Apical portion of abdomen, lateral view. 45. First valvifer and first valvula, lateral view. 46. Apical portion of first valvula. 47. Second valvula, lateral view. 48. Apical portion of second valvula. 49. Second valvifer and gonoplac, lateral view. Scale bars in $\mathrm{mm}$. 
its length; dorsoposterior margin fused to pygofer lobes, straight and oblique; ventral margin excavated basally, with rounded lobe at basal third, straight on posterior $2 / 3$, with short, thick setae grouped in line near midlength; lateral surface without macrosetae, but with few short setae near apex. In ventral view, pygofer (Fig. 38) with ventral margin folded inward, from base to apex, with short setae on inner surface. Anal tube membranous, without processes. Subgenital plate (Figs 36-39) short, with well developed pseudostyle; inner margin nearly straight; external margin with rounded lobe on basal half, overlapping pygofer laterally; apex of pseudostyle subacute, with thin setae along external margin and group of thicker setae on apex. Connective amorphous. Style (Figs 36, 40) long, approximately straight, apodeme and apophysis long, sub equal in length; apex rounded, curved dorsally. Aedeagus (Figs 41-42), with preatrium not developed; dorsal apodeme developed, lateral margins extended laterad and posterior margin extending to almost apex of shaft; shaft slightly curved dorsally, with height approximately constant from base to apex. In ventral view, aedeagus (Fig. 42) with shaft apex bifid; gonopore subapical.

\section{Female}

Terminalia. Sternite VII (Figs 43-44) ca two times wider than long; ventral surface with short setae; posterior margin with narrow and deep notch medially. Internal sternite VIII membranous. Pygofer (Figs 43-44) with many thin setae; ventral margin broadly rounded; apex obliquely truncated. Ovipositor slender, evenly curved dorsad, not surpassing pygofer apex. First valvifer (Fig. 45) triangular; anterior margins of both valvifers connected by sclerotized membrane. First valvula (Fig. 45) with dorsal and ventral margins, slightly convergent apically, ca 8 times longer than high at base; ventral interlocking device long, extending over basal $2 / 3$; dorsal sculpturing area areolate starting before the midlength; apical portion (Fig. 46) with ventral sculpture present only near apex, continuous with the dorsal sculpture, apex gradually tapered and acute. Second valvifer (Fig. 49) ca three times higher than long. Second valvula (Fig. 47) ca 10 times longer than high; dorsal and ventral margins parallel; dorsal margin with three distinct subapical teeth widely spaced; apical portion (Fig. 48) dorsal margin with two rounded notches forming one rounded tooth between apex and first subapical tooth; ventral margin without denticles and with one subapical tooth. Gonoplac (Fig. 49) four times longer than high; dorsoapical margin long with half length of gonoplac; external surface without dentiform cuticular projections; ventral margin broadly rounded, with few spaced macrosetae near ventral margin; apex rounded.

\section{Remarks}

Gehundra sordida is similar to G. galbina and G. cristalinensis sp. nov. in lacking long setae on ventral margin of pygofer, and is similar to G. cristalinensis sp. nov. in having the apex of style not foot-shaped. However, G. sordida can be easily separated by the subgenital plate with external margin with lobe limited to the basal half of pseudostyle (external margin with lobe occupying more than half length of pseudostyle in G. avulsa and G. cristalinensis sp. nov., and occupying entire length of pseudostyle in G. tricosa and G. galbina.

Key to males of Gehundra (G. pallida only known from the female)

1. Style with apex expanded, foot-shaped (Blocker 1976: 520, fig. 10) ….......................................... 2

- Style with apex tapered, not foot-shaped (Fig. 21) ........................................................................... 4

2. Subgenital plate with lobe of the external margin occupying more than half length of pseudostyle (Blocker 1976: 520, fig. 12) G. avulsa Blocker, 1976 (Peru)

- Subgenital plate with lobe of the external margin occupying entire length of pseudostyle (Blocker 1976: 520, fig. 13) 3

3. Pygofer with long setae on ventral margin (Blocker 1976: 520, fig. 7) 
4. Pygofer with long setae on ventral margin (Fig. 18). Subgenital plate with lobe of the external margin occupying more than half length of pseudostyle (Fig. 20)

G. cristalinensis sp. nov. (Brazil)

- Pygofer without long setae on ventral margin (Fig. 37). Subgenital plate with lobe of the external margin limited to the basal half of pseudostyle (Fig. 39) G. sordida (Baker, 1900) (Brazil)

\section{Discussion}

The genus Comanopa can be recognized by the forewing with vein separating appendix and first apical cell incomplete (evanescent apically); the pygofer with process (pygofer hooks) arising near apex, extending anterad, similar to Penestragania Beamer \& Lawson, 1945; the subgenital plates simple, slightly reduced in size, similar to Momoria Blocker, 1979; the style reduced in length; and the connective like a narrow semicircular band (Blocker 1979). In the new species of Comanopa proposed herein, the process of pygofer differs from the process present in species of Penestragania, because it is entirely fused to the lateral lobe of pygofer, resembling more an integument thickening than a process, whereas in species of Penestragania this process is separated from the lateral lobe by most of its length. However, the remaining species of Comanopa need to be studied to determine if this characteristic found in C. manancienis sp. nov. is unique for this species or is shared with other species of the genus.

The genus Gehundra can mainly be recognized by the forewing with vein separating appendix and first apical cell complete; the male sternite VIII very long, reaching the apex of pygofer, in repose; the subgenital plates with external margin lobed, overlapping the lateral portion of pygofer and with well developed pseudostyles; and the connective amorphous (Blocker 1976). Only two species of Gehundra were previously known from Brazil, G. pallida and G. sordida, both described based on a single female specimen. According to the descriptions and illustrations of Blocker (1979), G. sordida has the posterior margin of sternite VII with a narrow and deep notch medially (Fig. 43; Blocker 1979: 22, fig. 24) and G. pallida has the posterior margin evenly excavated, almost rounded (Blocker 1979: 22, fig. 23). Gehundra cristalinensis sp. nov. can be differentiated from G. pallida and G. sordida in having the posterior margin of the sternite VII with a broad and acute notch medially (Fig. 24).

The diversity and distribution of leafhoppers of the tribe Hyalojassini remain poorly known. The majority of species described from the Neotropical region don't have the male and female associated and are known based on a few specimens, commonly only by the holotype. Almost all studies which described neotropical species currently placed in this tribe are anterior to the 1980 s and considering only a few generic revisions are available and many species remain undescribed in Brazilian collections, this is a wide field to be explored.

\section{Acknowledgments}

This work was supported by a CNPq stipend (process 140815/2017-1). Many thanks to the anonymous reviewers who kindly made improvements to a preliminary version of this manuscript, the editorial team of the EJT, Dr Rodney R. Cavichioli (DZUP, curator of Hemiptera) for providing the infrastructure needed to develop this study, Dr Alexandre Specht (Empresa Brasileira de Pesquisa Agropecuária) and the collaborators Willian Rogers Ferreira de Camargo and Henrique Villas Boas Concone by the specimens of G. sordida studied herein.

\section{References}

Baker C.F. 1900. On some American species of Macropsis (Jassidae). Psyche 9: 55-59.

Blocker H.D. 1976. Three new genera of Neotropical Iassinae (Homoptera: Cicadellidae). Annals of the Entomological Society of America 69 (3): 519-522. https://doi.org/10.1093/aesa/69.3.519 
Blocker H.D. 1979. The Iassinae (Homoptera: Cicadellidae) of the western Hemisphere. Journal of the Kansas Entomological Society 52 (1): 1-70.

Blocker H.D. 1982. New species of Iassinae from the Neotropics (Homoptera: Cicadellidae). Journal of the Kansas Entomological Society 55 (4): 639-650.

Cavichioli R.R. \& Takiya D.M. 2012. Description of a new species of Wolfniana and new records of Rotigonalia (Hemiptera: Cicadellidae: Cicadellinae) from the state of Amazonas, Brazil. Zoologia 29 (1): 85-88. https://doi.org/10.1590/S1984-46702012000100011

Dai W. \& Dietrich C.H. 2015. A new genus of Iassinae (Hemiptera: Cicadellidae) from Peru and a new species of Daveyoungana Blocker \& Webb. Zootaxa 3946 (2): 285-295.

https://doi.org/10.11646/zootaxa.3946.2.10

Dai W., Dietrich C.H. \& Zhang Y. 2015. A review of the leafhopper tribe Hyalojassini (Hemiptera: Cicadellidae: Iassinae) with description of new taxa. Zootaxa 3911 (1): 1-42.

https://doi.org/10.11646/zootaxa.3911.1.1

Defea B.S. \& Paradell S.L. 2019. New South American genus of Iassinae (Hemiptera: Cicadellidae) and additional morphological characters for two Neotropical species of Neobalinae and Nioniinae. Austral Entomology 58 (4): 729-738. https://doi.org/10.1111/aen.12423

Dietrich C.H. 2005. Keys to the families of Cicadomorpha and subfamilies and tribes of Cicadellidae (Hemiptera: Auchenorrhyncha). Florida Entomologist 88: 502-517.

https://doi.org/10.1653/0015-4040(2005)88[502:KTTFOC]2.0.CO;2

Dietrich C.H., de Magalhães R.B. \& Takiya D.M. 2020. Revision of the endemic Malagasy leafhopper tribe Platyjassini (Hemiptera: Cicadellidae: Iassinae). European Journal of Taxonomy 695: 1-89.

https://doi.org/10.5852/ejt.2020.695

Domahovski A.C. 2019. New genera and species of Selenomorphini (Hemiptera: Cicadellidae: Iassinae), including redescription of Scaroidana Osborn, Pachyopsis Uhler and updated key to genera and species. Zootaxa 4711 (3): 517-544. https://doi.org/10.11646/zootaxa.4711.3.5

Domahovski A.C. 2020. New species of Bertawolia Blocker and Momoria Blocker (Cicadellidae: Iassinae: Hyalojassini) from Brazil, including notes about host plants. Zootaxa 4808 (3): 475-490.

https://doi.org/10.11646/zootaxa.4808.3.4

Domahovski A.C. \& Cavichioli R.R. 2019a. Acusana DeLong (Hemiptera: Cicadellidae: Gyponini), a genus not previously recorded in Brazil: description of four new species for the Brazilian fauna. Zootaxa 4571 (4): 531-543. https://doi.org/10.11646/zootaxa.4571.4.5

Domahovski A.C. \& Cavichioli R.R. 2019b. Three new species of Daveyoungana Blocker \& Webb (Hemiptera: Cicadellidae: Iassinae: Hyalojassini) from Brazil. Zootaxa 4571 (4): 477-488.

https://doi.org/10.11646/zootaxa.4571.4.2

Domahovski A.C. \& Cavichioli R.R. 2019c. Guaricicana, a new genus of Hyalojassini (Hemiptera: Cicadellidae: Iassinae) from the Brazilian Atlantic Forest. European Journal of Taxonomy 547: 1-12. https://doi.org/10.5852/ejt.2019.547

Domahovski A.C. \& Cavichioli R.R. 2020. Three new species of Polana (Varpulana) (Hemiptera: Cicadellidae: Gyponini) from Brazil, with updated key to males and taxonomic notes on the female genitalia. Zootaxa 4767 (4): 501-517. https://doi.org/10.11646/zootaxa.4767.4.1

Domahovski A.C., Gonçalves C.C., Takiya D.M. \& Cavichioli R.R. 2020. Description of two new species of Regalana and a new genus of Gyponini (Hemiptera: Cicadellidade: Iassinae). Zootaxa 4731 (1): 89-102. https://doi.org/10.11646/zootaxa.4731.1.6 
Freytag P.H. 2018. Three new species of Bythonia (Hemiptera: Cicadellidae: Iassinae) from South America. Entomological News 128 (1): 61-64. https://doi.org/10.3157/021.128.0108

Freytag P.H. \& Sharkey M. 2002. A preliminary list of the leafhoppers (Homoptera: Cicadellidae) of Colombia. Biota Colombiana 3: 235-283.

Gaiani M.A. 2017. Review of the genus Bythonia Oman 1936 with description of a new species and new record from Venezuela (Hemiptera, Cicadellidae, Iassinae). Zootaxa 4273 (3): 447-450.

https://doi.org/10.11646/zootaxa.4273.3.11

Gonçalves C.C., Dietrich H.D. \& Takiya D.M. 2020. A new genus of Hoplojassini from French Guiana (Hemiptera: Cicadellidae: Iassinae) and identification key for species of tribe. Zootaxa 4742 (2): 351358. https://doi.org/10.11646/zootaxa.4742.2.8

Hamilton K.G.A. 1981. Morphology and evolution of the Rhynchotan head (Insecta: Hemiptera, Homoptera). The Canadian Entomologist 113: 953-974. https://doi.org/10.4039/Ent113953-11

Kramer J.P. 1963. A key to the New World genera of Iassinae with reviews of Scaroidana and Pachyopsis (Homoptera: Cicadellidae). Bulletin of the Brooklyn Entomological Society 58 (2/3): 37-50. Available from https://www.biodiversitylibrary.org/part/177194 [accessed 31 Mar. 2021].

Krishnankutty S.M., Dietrich C.H., Dai W. \& Siddappaji M.H. 2016. Phylogeny and historical biogeography of leafhopper subfamily Iassinae (Hemiptera: Cicadellidae) with a revised tribal classification based on morphological and molecular data. Systematic Entomology 41 (3): 580-595. https://doi.org/10.1111/syen.12175

Linnavuori R.E. 1956. Neotropical Homoptera of the Hungarian National Museum and some other European museums. Annales Entomologici Fennici 22: 5-35.

Mejdalani G. 1998. Morfologia externa dos Cicadellinae (Homoptera, Cicadellidae): comparação entre Versigonalia ruficauda (Walker) (Cicadellini) e Tretogonia cribrata Melichar (Proconiini), com notas sobre outras espécies e análise da terminologia. Revista Brasileira de Zoologia 15: 451-544.

https://doi.org/10.1590/S0101-81751998000200015

Metcalf Z.P. 1966. General Catalogue of the Homoptera. Fascicle VI. Cicadelloidea. Part 15. Iassidae. United States Department of Agriculture, Agricultural Research Service, Washington DC.

Oman P.W. 1936. A generic revision of American Bythoscopinae and South American Jassinae. The Kansas University science bulletin 24: 343-420.

Available from https://www.biodiversitylibrary.org/part/33502 [accessed 31 Mar. 2021].

Oman P.W. 1949. The Nearctic leafhoppers (Homoptera: Cicadellidae). A generic classification and check list. Memoirs of the Entomological Society of Washington 3: 1-253.

Rakitov R.A. 1997. On differentiation of cicadellid leg chaetotaxy (Homoptera: Auchenorrhyncha: Membracoidea). Russian Entomological Journal 6: 7-27.

Wang X.Y., Wu Y.F. \& Dai R.H. 2018. Three new species of the leafhopper subfamily Iassinae (Hemiptera: Cicadellidae) from China. Zootaxa 4442 (3): 378-388. https://doi.org/10.11646/zootaxa.4442.3.2

Young D.A. 1968. Taxonomic study of the Cicadellinae (Homoptera: Cicadellidae). Part 1. Proconiini. Bulletin of the United States National Museum 261: 1-287. https://doi.org/10.5962/bhl.part.20869

Young D.A. 1977. Taxonomic study of the Cicadellinae (Homoptera: Cicadellidae). Part 2. New World Cicadellini and the genus Cicadella. Technical Bulletin of North Carolina Agricultural Experiment Station 239: 1-1135. 
Manuscript received: 18 September 2020

Manuscript accepted: 9 February 2021

Published on: 22 April 2021

Topic editor: Nesrine Akkari

Section editor: Christopher H. Dietrich

Desk editor: Pepe Fernández

Printed versions of all papers are also deposited in the libraries of the institutes that are members of the EJT consortium: Muséum national d'histoire naturelle, Paris, France; Meise Botanic Garden, Belgium; Royal Museum for Central Africa, Tervuren, Belgium; Royal Belgian Institute of Natural Sciences, Brussels, Belgium; Natural History Museum of Denmark, Copenhagen, Denmark; Naturalis Biodiversity Center, Leiden, the Netherlands; Museo Nacional de Ciencias Naturales-CSIC, Madrid, Spain; Real Jardín Botánico de Madrid CSIC, Spain; Zoological Research Museum Alexander Koenig, Bonn, Germany; National Museum, Prague, Czech Republic. 